\title{
Influence of terbutryne 〈Igran 50〉 on choline content in the grain of some winter wheat varieties
}

\author{
RENATA CISZEWSKA and ANNA SYKUT
}

Department of General Chemistry and Biochemistry, Agricultural University, Akademicka 13, 20-033 Lublin, Poland

〈Received: April 20, 1983〉

\begin{abstract}
The influence of terbutryne 〈Igran 50〉 on the accumulation of choline in the grain of three winter wheat varieties 〈'Holme', 'Kranich', 'Winetou'〉 was investigated in field experiments in the years $1977-1979$. Igran $50<50 \%$ S. A. $>$ was applied to the soil in a weed control dose $\langle 4$ $\mathrm{kg} / \mathrm{ha}\rangle$. Differences in choline content were found in the grain of the investigated wheat varieties. After application of the herbicide an insignificant decrease of the determined compound content was noted. These changes were dependent on the varieties of wheat and the meteorological conditions of plant vegetation. The climatic conditions exercised a greater influence on the choline content in grain than the applied herbicide. For this reason it appears from the agricultural point of view that the effect of terbutryne provoking only an insignificant Jecrease of the determined compound content in the investigated material is of no greater practical importance.
\end{abstract}

\section{INTRODUCTION}

Investigations on various aspects of herbicide application in agriculture comprise also qualitative and quantitative changes in the chemical composition of the crop plants in which weeds are controlled. The results of experiments in this field not only give a better knowledge of the mechanism of the complex action of herbicides, but may also be an indication for appropriate selection of herbicides, ensuring preservation of the full value of the crops.

Among herbicides recommended in winter cereal culture belong Igran 50 containing $50 \%$ of active substance - terbutryne, that is 2-methylthio-4-ethylamino-6-butylamino-s-triazine $\langle\mathrm{B}$ y r d y et al., 1976 $\rangle$. In studies on the influence of this herbicide on the chemical composition of the above ground parts of wheat, so far the content of dry matter, amino acids, proteins, sugars, lipids and mineral components were determined $\langle\mathrm{R}$ o 1 a and $\mathrm{P} \nmid$ o s z y ń s k i, 1974; 
Sienkiewicz et al., 1978; Szy m c a k and B i e r a t, 1980; $\mathrm{Szymczak}$ and Graje ta, 1980; W y b i r a l s ka and $\mathrm{Mar}$ k i e w i c z, 1980; C i s z e w s k a et al., 1984; S z y n a 1 et al., 1984). For the nutrient value of the cereal grain not only the content of the above mentioned basic components is decisive, but also the presence of vitamins and vitamin-like compounds. The content of these biologically active substances has been repeatedly taken into consideration in the evaluation of grain quality and of its products <C a l h o u m et al., 1958; 1960; W a g g l e et al., 1967; W i 1 s o n and Lorenz, 1979>.

To vitamin-like compounds, classified sometimes to the vitamin B group belongs choline 〈triethanolamine〉 $\langle\mathrm{W}$ a $\mathrm{g} \mathrm{n}$ e $\mathrm{r}$ and $\mathrm{F} \mathrm{ol} \mathrm{k} \mathrm{e} \mathrm{r} \mathrm{s,} \mathrm{1964;}$ M a c i e jew ska-P ot a p c z y k ow a, 1967). Choline deficit in the diet may be the cause of many pathological changes in living organisms, caused by disturbances in metabolic processes requiring the participation of this compound. Choline is a component of phospholipids which are of essential importance in the structure of cell membranes and transport through these membranes of some substances. It is also a substrate in acetylcholine synthesis a neurohormone taking part in transmission of nervous impulses in animals $\langle$ Voskresenski and $\mathrm{Maksimovich}, 1967$; V a sileva, $1975\rangle$. The role of acetylcholine in plant organisms, connected probably with processes controlled by phytochrome has so far not been elucidated $\langle\mathrm{K}$ o $\mathrm{p}$ c e w i c z, 1979 $>$. The biological function of choline is also manifested in its participation, as methyl group donor, after oxidation to glycinebetaine in many reactions leading to the arising of various compounds acting on the growth and development of plants and animals $\langle\mathrm{M}$ a c i e j e w s k a - P o t a p c z yk ow a, 1967; V osk resenski and Maksi movich, 1967).

In view of the manysided role of choline in living organisms, and particularly in the nutrition of humans and animals, investigations were undertaken in order to determine its content in the grain of some selected winter wheat varieties. The influence of terbutryne $\langle$ Igran 50〉 on choline accumulation in the experimental material was also analysed.

\section{MATERIAL AND METHODS}

The material investigated consisted of grain from three winter wheat varieties 〈Triticum aestivum L. var. 'Holme', 'Kranich', 'Winetou'> cultivated under field conditions in the years 1977-1979 in the locality Bielany near Wrockaw. The experiments were conducted by the Department of Ecology and Weed Control of the Institute of Soil Cultivation and Fertilization in Wroclaw / within the sub problem 09.3.03. $>$. The plots were established in four replications by the random blocks method. The surface area of the plots amounted to $10 \mathrm{~m}^{2}$. Soil type medium silt clay with rape as forecrop. For weed control Igran $50<$ Ciba-Geigy, 
Switzerland > was used containing 50 per cent terbutryne <2-methylthio-4-ethylamino-6-butylamine-s-triazine $\rangle$. The herbicide was applied in a dose of $4 \mathrm{~kg} / \mathrm{ha}$ three days after sowing the wheat. For laboratory examination mean samples of grain were taken from the particular plots. Chemical analyses were done in three replications. The data in Table 1 are means of results from three replications of analyses of the material from plots in four replications. The grain was comminuted in an electric mill so that the ground material would all pass through a sieve with $0.75 \mathrm{~mm}$ mesh. In thus prepared material total choline was determined by the method based on the reaction of this compound with Reineck's salt 〈i.e. ammonium salt of chromotetrarhodanohydric acid〉 and by colorimetric measurement of the absorption value of the acetone solution of the coloured complex formed. The measurements were performed with a Specol photocolorimetre at wavelength $530 \mathrm{~mm}$ in a $1 \mathrm{~cm}$ absorption cell. A calibration curve was prepared for choline chloride solutions $\langle\mathrm{E} \mathrm{r} \mathrm{m} \mathrm{a} \mathrm{k} \mathrm{o} \mathrm{v,} \mathrm{1972 \rangle .} \mathrm{Statistical}$ analysis of the results was done according to the orthogonal triple cross classification at the significance level $\mathrm{P}=0.05$.

\section{RESULTS AND DISCUSSION}

The results of choline content determinations in the investigated material are showed in Table 1 . The tested winter wheat varieties are characterized by a differentiated choline content in the grain. The highest content of this compound was found in the grain of the wheat variety 'Winetou' and the lowest in the grain of the wheat variety 'Kranich'. It should be mentioned that the choline content in the grain of the studied wheat varieties varied widely in the particular years of the experiment, what may indicate an influence of meteorological conditions on accumulation of this compound. The widest differences in the amount of choline in the studied material were noted in the years 1977 and 1979 in which differences in the amount of precipitation in the vegetation period were widest $\langle$ Table 2$\rangle$. The year 1977 in which the grain of the tested wheat varieties contained much more choline as compared with analogous data of the years 1978 and 1979 was characteristic by a higher mean air temperature, a high precipitation and an increased sky overcast. The high choline content in the experimental material of 1977 may have been to some extent connected with changes in dry weight content of the grain since in preceding studies in the same experiment the lowest dry weight content was found in the grain harvested in that year $\langle\mathrm{S} \mathrm{z} \mathrm{y} \mathrm{n}$ a 1 et al., 1984>.

When analysing the data concerning the influence of the herbicide applied on choline content in the wheat grain, it was found that most susceptible proved the variety 'Kranich' which in the group of tested varieties exhibited the lowest choline amount in the grain. In all years of the experiment a tendency was observed, after application of Igran 50, to a decrease of choline content in the 
Ta b l e 1

Influence of terbutryne (Igran 50) on the content of choline in winter wheat grain ( $\mathrm{mg}$ choline chloride in $100 \mathrm{~g} \mathrm{~d} . \mathrm{m}$.)

\begin{tabular}{|c|c|c|c|c|c|c|}
\hline \multirow{2}{*}{ Variety } & \multirow{2}{*}{ Herbicide } & \multicolumn{3}{|c|}{ Years } & \multirow{2}{*}{$\overline{\mathbf{x}}$} & \multirow{2}{*}{$\overline{\mathbf{x}}$} \\
\hline & & 1977 & 1978 & 1979 & & \\
\hline \multirow{2}{*}{ 'Holme' } & Control & 196.23 & 172.06 & 164.40 & 177.56 & \multirow{2}{*}{173.32} \\
\hline & Igran 50 & 180.91 & 168.23 & 158.13 & 169.09 & \\
\hline \multirow{2}{*}{ 'Kranich' } & Control & 200.20 & 167.89 & 145.12 & 171.07 & \multirow{2}{*}{164.00} \\
\hline & Igran 50 & 165.52 & 161.68 & 143.57 & 156.92 & \\
\hline \multirow{2}{*}{ 'Winetou' } & Control & 227.14 & 188.67 & 187.00 & 200.94 & \multirow{2}{*}{197.78} \\
\hline & Igran 50 & 220.77 & 185.97 & 177.12 & 194.62 & \\
\hline \multirow{2}{*}{$\overline{\mathbf{x}}$} & Control & 207.86 & 176.21 & 165.51 & 183.19 & \\
\hline & Igran 50 & 189.07 & 171.96 & 159.61 & 173.54 & \\
\hline$\overline{\mathbf{x}}$ & & 198.46 & 174.08 & 162.56 & 178.37 & \\
\hline $\begin{array}{c}\text { LSD } \\
\mathbf{P}=\mathbf{0 . 0 5}\end{array}$ & $\begin{array}{l}\text { for varieties (A) } \\
\text { for herbicide (B) } \\
\text { for years (C) }\end{array}$ & $\begin{array}{l}3.54 \\
2.40 \\
3.54\end{array}$ & $\begin{array}{l}\text { for inter } \\
\text { for inter } \\
\text { for intel }\end{array}$ & 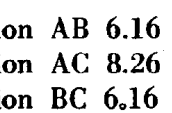 & for interaction & n $\mathrm{ABC} \quad 13.30$ \\
\hline
\end{tabular}

Ta b l e 2

Meteorological data from Meteorological Station in Legnica-Bartoszẹwo

\begin{tabular}{|c|c|c|c|c|c|c|c|c|c|}
\hline Meteorological conditions & Year & III & IV & $\mathbf{V}$ & $\begin{array}{l}\text { Months } \\
\text { VI }\end{array}$ & VII & VIII & $\begin{array}{l}\text { In vegetation } \\
\text { means }\end{array}$ & $\begin{array}{l}\text { period } \\
\text { total }\end{array}$ \\
\hline Temperature of air ${ }^{\circ} \mathrm{C}$ & $\begin{array}{l}1977 \\
1978 \\
1979\end{array}$ & $\begin{array}{l}6.9 \\
5.0 \\
\mathbf{3 . 8}\end{array}$ & $\begin{array}{l}6.2 \\
6.7 \\
6.9\end{array}$ & $\begin{array}{l}12.4 \\
12.0 \\
14.2\end{array}$ & $\begin{array}{l}17.1 \\
15.4 \\
18.9\end{array}$ & $\begin{array}{l}16.7 \\
16.0 \\
15.5\end{array}$ & $\begin{array}{l}16.4 \\
16.1 \\
17.2\end{array}$ & $\begin{array}{l}12.6 \\
11.8 \\
11.9\end{array}$ & \\
\hline Rainfall (mm) & $\begin{array}{l}1977 \\
1978 \\
1979\end{array}$ & $\begin{array}{l}31 \\
.36 \\
33\end{array}$ & $\begin{array}{l}37 \\
42 \\
35\end{array}$ & $\begin{array}{l}88 \\
50 \\
24\end{array}$ & $\begin{array}{r}100 \\
35 \\
35\end{array}$ & $\begin{array}{r}144 \\
68 \\
68\end{array}$ & $\begin{array}{r}191 \\
106 \\
27\end{array}$ & & $\begin{array}{l}591 \\
337 \\
219\end{array}$ \\
\hline Sky overcast & $\begin{array}{l}1977 \\
1978 \\
1979\end{array}$ & $\begin{array}{l}7.9 \\
7.5 \\
7.8\end{array}$ & $\begin{array}{l}7.9 \\
7.5 \\
7.9\end{array}$ & $\begin{array}{l}7.4 \\
7.2 \\
5.1\end{array}$ & $\begin{array}{l}6.3 \\
6.0 \\
6.1\end{array}$ & $\begin{array}{l}7.5 \\
6.7 \\
7.8\end{array}$ & $\begin{array}{l}7.7 \\
7.3 \\
6.8\end{array}$ & $\begin{array}{l}7.4 \\
6.9 \\
6.7\end{array}$ & \\
\hline
\end{tabular}


grain of the winter wheat varieties. A significant decrease of the level of this compound was, however, recorded only in 1977. The differences in mean choline values in samples from the plots treated with the herbicide and the control ones were as follows: in $1977-9.04 \%$, in $1978-2.41 \%$, and in $1979-3.56 \%$ of the total choline content in the control samples of the particular years. These data are evidence that the negative effect of terbutryne on choline accumulation in the grain depended not only on the wheat variety, but also on the meteorological conditions, and particularly on the amount of precipitation and temperature in the vegetation period. As mentioned, in 1977 when precipitation was high and the mean air temperature highest the decrease of the choline level in the grain as the effect of the herbicide was most pronounced. In 1978, with lower air temperature and a moderate amount of precipitation in the vegetation period, significant changes were not observed in the choline content after herbicide application. In the same field experiment a significant decrease in total protein content was noted only in the year 1977 in wheat grain after the use of Igran 50. In the subsequent years a reversed action of this herbicide was even observed $\langle\mathrm{C}$ i s z e w s $\mathrm{k}$ a et al., 1984 $\rangle$. On the basis of the here presented results it may be said that meteorological conditions influenced to a much higher degree on the choline content in the studied material than did the use of Igran 50. Comparison of the mean values for choline content in the examined grain indicates that the effect of the herbicide was limited to a decrease of choline content by about 5 per cent in relation to its content in the grain from the control plots, whereas the difference in choline level between the samples in the particular years reached 20 per cent. It would seem, therefore, from the agricultural point of view that the decrease of choline content in wheat grain caused by terbutryne application is of no major practical importance.

\section{REFERENCES}

B y r d y S., Gó r e c k i K., Ła s z c z E., 1976. Pestycydy. PWRiL, Warszawa.

C a 1 h o u m W. K., B e c h t e l W. G., B r a d l e y W. B., 1958. The vitamin content of wheat, flour and bread. Cereal Chem. 35: 350-359.

C a l h o u m W. K., H e p burn F. N., B r a d le y W. B., 1960. The distribution of the vitamins of wheat in commercial mill products. Cereal Chem. 37: 755-761.

C i s z e w s k a R., W ój c i k W., S y k u t A., S z y n a 1 J., 1984. Wpływ herbicydów triazynowych i mocznikowych na zawartość frakcji białkowych i białka ogólnego w ziarnie trzech odmian pszenicy ozimej. Rocz. Nauk Rol., Ser. E 〈Ochrona roślin〉 (in press).

E r m a k ov A. I. 〈Ed.〉, 1972. Metody biokhimicheskogo issledovaniya rastenii. "Kolos". Leningrad.

K o p ce w i c z J., 1979. Fitochrom jako receptor światła w procesach fotomorfogenezy roślin. Postępy Biochemii 25: 211-228.

M a c i e j e w s k a - P o t a p c z y k ow a W., 1967. Substancje wzrostowe roślin. PWRiL, Warszawa.

R o l a H., Pło s z y ń s k i M., 1974. Badania nad fitotoksycznym wpływem herbicydów na 
różne odmiany pszenicy ozimej w początkowych fazach jej rozwoju. Pamiętnik Puławski 60: 95103.

Sie n ki e wi c z J., R un ow ska-H r yńczuk B., P ło s z y ńs k i M., 1978. Działanie herbicydów Igranu 50 i Mixi Tok $\mathrm{S}$ przy różnym zagęszczeniu gleby na wzrost siewek pszenicy ozimej odmiany Eros. Pamiętnik Puławski 70: 37-45.

S z y m c z a k J., B i e r n a t J., 1980. Wpływ herbicydów na zawartość wapnia i żelaza w ziarnie różnych odmian pszenicy. Bromat. Chem. Toksykol. 13: 139-143.

S z y m c z a k J., G r a j e t a H., 1980. Wpływ herbicydów stosowanych w uprawie pszenicy na zawartość lipidów w ziarnie. Bromat. Chem. Toksykol. 13: 133-138.

Sz y nal J., C is ze w sk a R., S y k u t A., W ó j c i k W., 1984. Wpływ herbicydów mocznikowych i triazynowych na zawartość składników mineralnych w ziarnie wybranych odmian pszenicy ozimej. Bromat. Chem. Toksykol. 17: 63-68.

W a g g l e D. H., L a m be r $t$ M. A., M i 11 e r G. D., F a r ve 11 E.P., D e y o e C. W., 1967. Extensive analyses of flours and millfeeds made from nine different wheat mixes. II. Amino acids, minerals, vitamins and gross energy. Cereal Chem. 44: 48-52.

W a g n e r A. F., F o 1 k e r s K., 1964. Vitamins and coenzymes. Interscience Publishers. John Wiley and Sons 〈ed.〉, New York-London-Sydney.

$V$ a s i l e v a E. D., 1975. O mekhanizmie lipotropnogo deistviya kholina i vozmozhnom uchastii fosfolipidov v okislenii zhirnykh kislot. Usp. sovr. biol. 79: 371-386.

W i 1 s o n J.E., L o r e n z K., 1979. Biotin and cholin in wheats and wheat flours. Lebensm. Wiss. u. Technol. 12: 72-75.

Vosk resensk i O. N., M a k s i m ovi c h Ya., B., 1967. Kholin i ego biologicheskaya rol. Usp. sovr. biol. $64:$ 53-74.

W y b i e r a l s k a A., M a r k i e w i c z E., 1980. Zawartość aminokwasów w ziarnie pszenicy traktowanej herbicydami. Bromat. Chem. Toksykol. 13: 7-12.

\section{Wpływ terbutryny 〈Igranu 50〉 na zawartość choliny w ziarnie niektórych odmian pszenicy ozimej}

\section{St reszczen ie}

W doświadczeniach polowych, w latach 1977-1979 przebadano wpływ terbutryny $\langle$ Igran 50 $\rangle$ na nagromadzanie się choliny w ziarnie 3 odmian pszenicy ozimej 〈'Holme', 'Kranich', 'Winetou'〉. Igran $50\langle 50 \%$ S. A. $\rangle$ stosowano doglebowo w dawce zalecanej do zwalczania chwastów $\langle 4 \mathrm{~kg} / \mathrm{ha}\rangle$. Wykazano istotne różnice $w$ zawartości choliny w ziarnie badanych odmian pszenicy. Po stosowaniu herbicydu stwierdzono nieznaczny spadek zawartości oznaczanego związku. Zmiany te uzależnione były zarówno od odmiany pszenicy jak i warunków meteorologicznych w okresie wegetacji roślin. Warunki klimatyczne wywierały większy wpływ na zawartość choliny w ziarnie niż stosowany herbicyd. $\mathrm{Z}$ tych względów wydaje się, że $\mathrm{z}$ rolniczego punktu widzenia, działaniu terbutryny powodującemu tylko nieznaczne obniżenie zawartości oznaczonego związku w analizowanym materiale nie można przypisać większego praktycznego znaczenia. 